\title{
Genetic Relationship Between Interleukın-6 rs1800796 Variants, Interleukın-6 Plasma Levels and Susceptibility to Type 2 Diabetes Mellitus and Diabetic Nephropathy
}

\section{Nezaket COBAN}

Artvin Coruh University: Artvin Coruh Universitesi

Aysegul Bayramoglu ( $\square$ atbayramoglu@gmail.com )

Artvin Coruh University: Artvin Coruh Universitesi https://orcid.org/0000-0001-8567-807X

\section{Zeynep TEMIZ}

Artvin Coruh University: Artvin Coruh Universitesi

\section{Research Article}

Keywords: Type-2 Diabetes, Diabetic Nephropathy, IL-6 gene, IL-6 level, rs1800796, RFLP

Posted Date: July 8th, 2021

DOI: https://doi.org/10.21203/rs.3.rs-608858/v1

License: (a) (i) This work is licensed under a Creative Commons Attribution 4.0 International License. Read Full License 


\section{Abstract}

Type 2 diabetes mellitus (T2DM) is very common worldwide and genetically heterogeneous. One of the microvascular complications is diabetic nephropathy (DN). In recent years, T2DM has been described as a disease caused by chronic inflammation. The imbalance between pro- and anti-inflammatory cytokines causes inflammation. One of the candidate genes associated with T2DM and DN is the Interleukin-6 (IL-6) gene, one of the pro-inflammatory cytokines. This study was conducted to determine the polymorphism frequencies of the IL- 6 gene rs 1800796 and investigate the role of this polymorphism in the development of T2DM and DN. Genomic DNA that was obtained from 261 people was used in the study. IL-6 gene rs 1800796 polymorphism was determined using the PCR, restriction fragment length polymorphism (RFLP) and electrophoresis. IL- 6 gene PCR products were discontinued by treatment with restriction enzyme $B s r B I$ and were analyzed in $2 \%$ agarose gel electrophoresis. IL-6 (Bioassay technology laboratory, Shangai, China) level was examined by enzyme-linked immunosorbent assay (ELISA) using a commercial kit. The results were statistically analyzed. The frequencies of rs 1800796 genotypes were found to be GG $70.7 \%, \mathrm{GC} 28.5 \%$, CC $0.8 \%$ in the control group and GG $87.8 \%$, GC $9.9 \%$, CC 2.3\% in T2DM patients. Although there was a statistically significant difference between the control group and the T2DM patient group in genotype and allele frequencies, there was no significant difference in $D N$. The $G$ allele frequency was also significantly higher in the T2DM group ( $p=0.000$ ). IL-6 levels were determinated increased in patients with Type-2 diabetes compared to the control group. However; there was no significant statistically. We can say that IL-6 rs 1800796 polymorphism is related to T2DM and $\mathrm{G}$ allele can be used as a useful genetic marker; this polymorphism is not related to $\mathrm{DN}$, though.

\section{Introduction}

Inflammation caused by an imbalance between pro- and anti-inflammatory cytokines causes T2DM and its complications [1]. Recently, T2DM has been described as a metabolic pro-inflammatory disease which is characterized by chronic hyperglycemia and increased circulatory cytokine levels [2]. In chronic low-grade inflammation, which is defined as a risk factor for the development of T2DM, increases circulating amounts of pro-inflammatory cytokines such as tumor necrosis factor-a (TNF-a), IL-6, and C- reactive protein (CRP). These cytokines are stated to cause insulin resistance development, as well as $\beta$ cell death, and ultimately T2DM by weakening insulin signaling, preventing insulin sensitivity and effect $[3,4]$. Especially in abdominal obesity (from abdominal adipose tissue), large amounts of inflammatory cytokines such as TNF- $a$ and IL-6 are secreted, and these cytokines by stimulating the production of CRP in the liver, trigger chronic inflammation [5]. IL-6 levels increase in obese individuals and patients with T2DM. IL-6 level decreases with the reduction of fat mass in obesity [6]. IL-6 plays an important role in regulating the energy balance with its effects on glucose metabolism by regulating the effects of insulin [7]. IL-6 is secreted by both immune cells and adipose tissue [8]. IL-6 is also produced from glomerular mesangial cells [9].

One of the most important complications of T2DM is DN. Inflammatory cytokines such as IL-6 have been recognized as having an important role in the pathogenesis and progression of DN [10]. Studies have shown that the $-572 \mathrm{G} / \mathrm{C}$ polymorphism ( $\mathrm{rs} 1800796$ ) found in the IL 6 gene promoter region may affect IL 6 gene transcription and serum levels $[8,9]$. Recently, several epidemiological studies have also been conducted to 
evaluate the relationship between IL6 gene rs1800796 polymorphism and T2DM and DN risk in various populations $[8,9,11,12]$.

Based on the relationship between inflammation and T2DM, we thought that genetic variations in the IL-6 gene, one of the pro-inflammatory cytokines, may cause susceptibility to the disease by altering the gene's function or expression, and in our study, we aimed to determine the frequency of variants of the IL- 6 gene in patients with T2DM and DN and to investigate the relationship with T2DM and DN.

\section{Materials And Methods}

Peripheral blood samples were obtained from 131 patients [80 patients without $D N\left(D^{-}\right)$and 51 with DN $\left(\mathrm{DN}^{+}\right)$] who applied to the Artvin State Hospital internal medicine department. The control group consisted of volunteers who came for a routine health screening with no evidence or family history of T2DM (130 volunteers). T2DM was diagnosed by qualified clinicians based on fasting blood glucose (FBG) $\geq 7.0 \mathrm{mmol} / \mathrm{l}$ levels and normoalbuminuria and $\mathrm{HbA} 1 \mathrm{c}(6.5 \%)$ for two consecutive routine screening readings. This study was approved by the local ethics committee of Karadeniz Technical University (Protokol number: 2019/164), Turkey. An informed consent was obtained from all patients prior to inclusion in this study in accordance with the Declaration of Helsinki.

Genomic DNA was extracted using DNA isolation Kit (EZ-10 Spin Colon Blood Genomic DNA Minipreps Kit, Biotechnology Department Bio Basic Inc., Markham, Ontario, Canada). The isolated DNA samples were amplified with the PCR conditions and primers for the IL-6 gene indicated in Table 1. After amplification, all PCR products were stored at $4^{\circ} \mathrm{C}$ till the next procedure. After the amplified PCR products were checked by using agarose gel electrophoresis, a 164-bp fragment was cleaved with $1 \mathrm{U} B s r B \mid$ restriction endonuclease (NEB, R0102S) according to the manufacturer's instructions. All PCR products obtained from the digestion reaction were separated using $2 \%$ agarose gel electrophoresis. The results were valued via gel analysis software (LabWorks, Cambridge, UK). Following cleavage with BsrBl restriction endonuclease, three different genotypes were determined including CC (164-bp), GC (164 - 101, and 63-bp) and GG (101 and 63-bp). 
Table 1

Primers and PCR conditions for IL-6 gene rs1800796 polymorphism

\begin{tabular}{|c|c|c|c|}
\hline \multicolumn{4}{|l|}{ PRIMERS } \\
\hline \multicolumn{4}{|c|}{ Forward : 5'- GGAGACGCCTTGAAGTAACTGC- 3' } \\
\hline \multicolumn{4}{|c|}{ Backward : 5'- GAGTTTCCTCTGACTCCATCGCAG- 3' } \\
\hline \multicolumn{4}{|l|}{ PCR CONDITION } \\
\hline Cyle & Number of Cycles & Tempature (+) & Time \\
\hline Initial Denaturation & 1 & $94^{\circ} \mathrm{C}$ & $7 \min$ \\
\hline Denaturation & & $94^{\circ} \mathrm{C}$ & $30 \mathrm{sec}$ \\
\hline Annealing & 35 & $59^{\circ} \mathrm{C}$ & $40 \mathrm{sec}$ \\
\hline Extension & & $72^{\circ} \mathrm{C}$ & $40 \mathrm{sec}$ \\
\hline Final extension & 1 & $72^{\circ} \mathrm{C}$ & $7 \mathrm{~min}$ \\
\hline Hold & & $4^{\circ} \mathrm{C}$ & $\infty$ \\
\hline
\end{tabular}

IL-6 (Bioassay technology laboratory, Shangai, China) level was examined by enzyme-linked immunosorbent assay (ELISA) using a commercial kit.

\section{Statistical Analysis}

Pearson Chi Square test, Independent Two Sample t test, Mann-Whitney U test, and one-way ANOVA p value were used to compare the categorical variables (allele, genotype, biochemical parameters, etc.) between groups. Statistical Package for Social Sciences software (SPSS v.19 package program) was used to analyze the data. The Shapiro-Wilk test was used for the normality. The $p$ values $<0.05$ were considered to be statistically significant. The odds ratio (OR) were estimated with $95 \%$ confidence interval (95\% Cl) and the probability value ( $p$ value) of less than $5 \%$ was considered to be statistically significant. Sampling number was determined by power analysis.

\section{Results}

In our study; There were statistically significant differences between the patient and control groups in terms of weight $(p=0.000)$, height $(p=0.001)$, BMI $(p=0.000)$, Fasting Glucose $(p=0.000)$, Postprandial Glucose $(p=0.000), H_{b A} C(p=0.003)$, Serum Creatinine $(p=0.020)$, Systolic Blood Pressure $(p=0.000)$. There was no statistically significance in age $(p=0.076)$, total cholesterol $(p=0.742), \operatorname{HDL}(p=0.149), \operatorname{LDL}(p=0.493)$, triglycerides ( $p=0.874)$, Diastolic Blood Pressure $(p=0.12)$ and IL-6 enzyme $(p=0.075)$ between the control group and patients with T2DM and DN (Table 2). 
Table 2

Some personal characteristics of the control and T2DM + DN group

\begin{tabular}{|c|c|c|c|}
\hline Parameters & $\begin{array}{l}\text { Control } \\
\text { mean } \pm \text { sd }\end{array}$ & $\begin{array}{l}\mathrm{T} 2 \mathrm{DM}+\mathrm{DN} \\
\text { mean } \pm \mathrm{sd}\end{array}$ & $\mathbf{p}$ \\
\hline Age(Year) & $55.63 \pm 10.65$ & $60.44 \pm 12.70$ & $\star 0.076$ \\
\hline Height (cm ) & $1.67 \pm 0.079$ & $1.63 \pm 0.077$ & $\star 0.001$ \\
\hline Weight (kg) & $75.40 \pm 12.81$ & $83.46 \pm 15.24$ & $\star 0.000$ \\
\hline $\mathrm{BMI}\left(\mathrm{kg} / \mathrm{m}^{2}\right)$ & $26.93 \pm 5.37$ & $31.19 \pm 5.73$ & $\star \star 0.000$ \\
\hline Fasting Glucose (mg/dl) & $93.13 \pm 10.28$ & $165.09 \pm 65.55$ & $\star \star 0.000$ \\
\hline Postprandial Glucose (mg/dl) & $133.66 \pm 38.09$ & $236.01 \pm 95.91$ & $\star \star 0.000$ \\
\hline $\mathrm{HbA}_{1} \mathrm{C}(\%)$ & $7.33 \pm 8.02$ & $7.51 \pm 6.54$ & $\star \star 0.003$ \\
\hline Serum Creatinine $(\mathrm{mg} / \mathrm{dl})$ & $0.79 \pm 0.28$ & $1.07 \pm 1.30$ & $\star 0.020$ \\
\hline Systolic Blood Pressure $(\mathrm{mmHg})$ & $124.15 \pm 11.53$ & $135.84 \pm 21.44$ & $\star \star 0.00$ \\
\hline Diastolic Blood Pressure (mmHg) & $77.56 \pm 9.09$ & $80.68 \pm 13.55$ & $\star \star 0.12$ \\
\hline Total Cholesterol (mg/dl) & $186.72 \pm 42.54$ & $197.03 \pm 53.25$ & $\star \star 0.742$ \\
\hline $\mathrm{HDL}(\mathrm{mg} / \mathrm{dl})$ & $51.97 \pm 32.68$ & $44.35 \pm 13.28$ & $\star \star 0.149$ \\
\hline $\mathrm{LDL}(\mathrm{mg} / \mathrm{dl})$ & $112.16 \pm 32.04$ & $120.40 \pm 42.49$ & $\star \star 0.493$ \\
\hline Triglycerides (mg/dl) & $176.12 \pm 102.35$ & $179.22 \pm 116.99$ & $\star * 0.874$ \\
\hline IL-6 Enzyme (pg/ml) & $0.85 \pm 0.48$ & $1.00 \pm 0.60$ & $\star * 0.075$ \\
\hline
\end{tabular}

The genotype distributions and allele frequencies of the IL- 6 gene rs 1800796 in the control group, the T2DM and DN patient groups are shown in Table 3. The IL-6 rs 1800796 genotype frequency was found to be GG $70.7 \%$, GC $28.5 \%$, CC $0.8 \%$ in the control group and GG $87.8 \%$, GC $9.9 \%$ and CC $2.3 \%$ in the patient group. The frequency of rs 1800796 genotype in patients with DN was found to be GG $80.4 \%$, GC $17.6 \%$ and CC $2.0 \%$. In patients without DN, GG was found to be $82.5 \%, \mathrm{GC} 15.0 \%$ and $\mathrm{CC} 2.5 \%$. The control group had a higher frequency of GC genotype than T2DM patients $(\mathrm{OR}=0.281,95 \% \mathrm{Cl}=0.141-0.559 ; \mathrm{p}=0.000)$. T2DM patients had a higher frequency $\mathrm{CC}$ genotype than the control group $(\mathrm{OR}=2.4,95 \% \mathrm{Cl}=0.245-23.458 ; \mathrm{p}=$ $0.437)$. The $G$ allele frequency was also significantly higher in T2DM group $(p=0.000)$. There was no statistically significant difference between DN and without DN patients in terms of numbers and percentages of genotypes of IL-6 rs 1800796. 
Table 3

Distribution of alleles and genotypes of IL-6 rs1800796 in T2DM patients with/without nephropathy and in controls

\begin{tabular}{|c|c|c|c|c|c|c|c|c|}
\hline $\begin{array}{l}\text { IL-6 } \\
\text { Genotype }\end{array}$ & $\begin{array}{l}\text { Control } \\
(n=130) \\
n(\%)\end{array}$ & $\begin{array}{l}\text { T2DM } \\
(n=131) \\
n(\%)\end{array}$ & $p^{*}$ & $\begin{array}{l}\text { OR } \\
(95 \% \mathrm{Cl})\end{array}$ & $\begin{array}{l}\text { DN- } \\
(n=80) \\
n(\%)\end{array}$ & $\begin{array}{l}\text { DN+ } \\
(n=51) \\
n(\%)\end{array}$ & $p^{*}$ & $\begin{array}{l}\text { OR } \\
(95 \% \mathrm{Cl})\end{array}$ \\
\hline GG & $92(70.7)$ & 115(87.8) & & Reference & $66(82.5)$ & $41(80.4)$ & & Reference \\
\hline $\mathrm{GC}$ & $37(28.5)$ & 13(9.9) & 0.000 & $\begin{array}{l}0.281 \\
(0.141- \\
0.559)\end{array}$ & $12(15.0)$ & $9(17.6)$ & 0.696 & $\begin{array}{l}1.20 \\
(0.46- \\
3.11)\end{array}$ \\
\hline $\mathrm{CC}$ & $1(0.8)$ & $3(2.3)$ & 0.437 & $\begin{array}{l}2.4 \\
(0.245- \\
23.458)\end{array}$ & $2(2.5)$ & $1(2.0)$ & 0.860 & $\begin{array}{l}0.80 \\
(0.07- \\
9.16)\end{array}$ \\
\hline Alleles & & & & & & & & \\
\hline G & $221(74.7)$ & $\begin{array}{l}243 \\
(89.3)\end{array}$ & 0.000 & $\begin{array}{l}\text { Reference } \\
0.351\end{array}$ & 144(90) & $91(89.2)$ & 0.838 & $\begin{array}{l}\text { Reference } \\
1.08\end{array}$ \\
\hline C & 75 (25.3) & $29(10.7)$ & & $\begin{array}{l}(0.220- \\
0.560)\end{array}$ & $16(10)$ & 11(10.8) & & $\begin{array}{l}(0.48- \\
2.44)\end{array}$ \\
\hline
\end{tabular}

Different models of gene inheritance were evaluated to check any predisposition to elevated risk or protection against T2DM and DN by comparing the two groups (Table 4 and Table 5). According to the inheritance model, GC-CC (OR: $0.33,95 \% \mathrm{Cl}=0.17-0.64 ; \mathrm{p}=0.000)$ genotype was significantly associated with T2 DM. 
Table 4

Analysis of the association of T2DM/control and IL-6 rs1800796 polymorphism in different models of inheritance

\begin{tabular}{|c|c|c|c|c|c|}
\hline \multirow[t]{3}{*}{ Inheritance Model } & Genotype & $\begin{array}{l}\text { Control } \\
(n=130)\end{array}$ & $\begin{array}{l}\text { T2DM } \\
(n=131)\end{array}$ & OR $(95 \% \mathrm{Cl})$ & $p^{*}$ \\
\hline & & $\mathrm{n}$ & $\mathbf{n}$ & & \\
\hline & & $\%$ & $\%$ & & \\
\hline \multirow[t]{4}{*}{ Dominant } & GG & 92 & 115 & Reference & 0.000 \\
\hline & & $(70.8)$ & $(87.8)$ & $0.33(0.17-0.64)$ & \\
\hline & GC-CC & 38 & 16 & & \\
\hline & & $(29.2)$ & $(12.2)$ & & \\
\hline \multirow[t]{4}{*}{ Recessive } & $\mathrm{CC}$ & 1 & 3 & Reference & 0.317 \\
\hline & & $(0.8)$ & $(2.3)$ & $0.33(0.03-3.22)$ & \\
\hline & GG-GC & 129 & 128 & & \\
\hline & & $(99.2)$ & $(97.7)$ & & \\
\hline \multicolumn{6}{|c|}{ 95\% Cl: 95\% confidence interval. } \\
\hline
\end{tabular}


Table 5

Analysis of the association of DN+ /DN- and IL-6 rs1800796 polymorphism in different models of inheritance

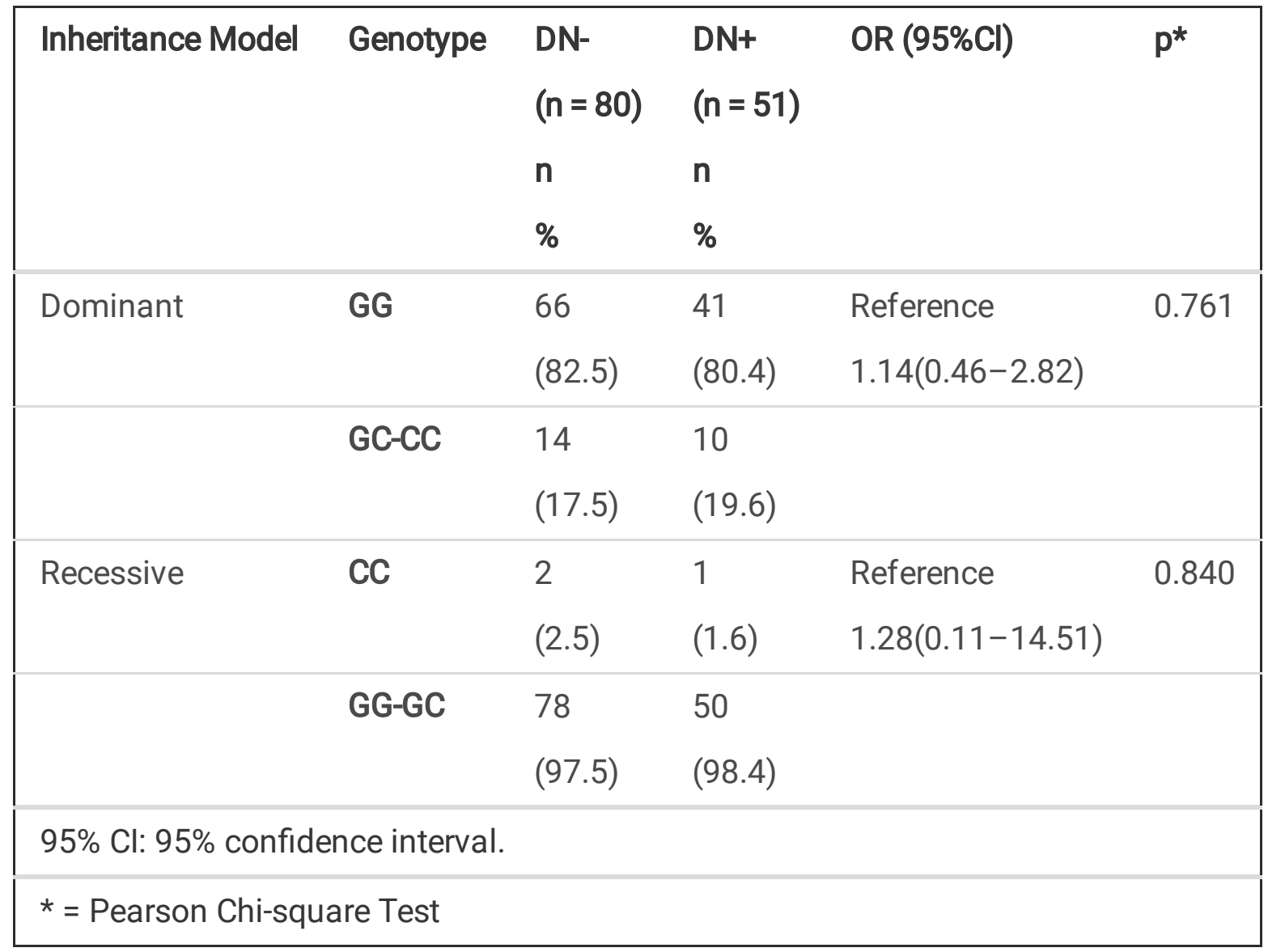

According to the GG, GC and CC genotypes total cholesterol $(p=0.886), \operatorname{HbA1c}(p=0.077)$, creatine $(p=$ $0.518)$, triglyceride $(p=0.876), \mathrm{HDL}(p=0.447), \operatorname{LDL}(p=0.982)$, systolic blood $(p=0.506)$, diastolic blood pressure $(p=0.303)$, weight $(p=0.919)$ and BMI $(p=0.132)$,, there were no statistically significant difference (Table 6). 
Table 6

Genotype distributions of IL-6 Gene rs 1800796 according to some clinical parameters of T2DM and DN.

\begin{tabular}{|c|c|c|c|c|}
\hline \multirow[t]{2}{*}{ Parameters } & \multicolumn{3}{|l|}{ Genotip } & \multirow[t]{2}{*}{$\mathbf{p}$} \\
\hline & GC & $\mathrm{CC}$ & & \\
\hline Total Cholesterol(mg/dl) & $197.90 \pm 55.23$ & $190.66 \pm 38.80$ & $196.00 \pm 0.00$ & *0.886 \\
\hline Triglycerides(mg/dl) & $181.09 \pm 121,34$ & $164.93 \pm 72.82$ & $166.00 \pm 0.00$ & $\star 0.876$ \\
\hline $\mathrm{HbA}_{1} \mathrm{C}(\%)$ & $7.07 \pm 4.35$ & $11.56 \pm 16.57$ & $7.60 \pm 1.25$ & $\star 0.077$ \\
\hline Serum Creatinine(mg/dl) & $1.13 \pm 1.38$ & $0.69 \pm 0.09$ & $0.82 \pm 0.26$ & $\star 0.518$ \\
\hline Systolic Blood Pressure $(\mathrm{mmHg})$ & $135.59 \pm 20.79$ & $136.66 \pm 25.81$ & $160.00 \pm 0.00$ & $\star \star 0.506$ \\
\hline Diastolic Blood Pressure (mmHg) & $80.77 \pm 13.74$ & $78.66 \pm 10.60$ & $100.00 \pm 0.00$ & $\star \star 0.303$ \\
\hline $\mathrm{HDL}(\mathrm{mg} / \mathrm{dl})$ & $44.86 \pm 13.53$ & $40.46 \pm 10.19$ & $39.20 \pm 0.00$ & $\star 0.447$ \\
\hline $\operatorname{LDL}(\mathrm{mg} / \mathrm{dl})$ & $120.47 \pm 43.70$ & $118.53 \pm 31.49$ & $124.00 \pm 0.00$ & *0.982 \\
\hline Weight (Kg) & $77.605 \pm 14.45$ & $76.833 \pm 14.57$ & $80.666 \pm 10.21$ & *0.919 \\
\hline $\mathrm{BMI}\left(\mathrm{kg} / \mathrm{cm}^{2}\right)$ & $30.82 \pm 5.59$ & $33.48 \pm 6.38$ & $37.17 \pm 0.00$ & $\star 0.132$ \\
\hline \multicolumn{5}{|l|}{ *= One way ANOVA } \\
\hline$\star \star=$ Independent Two Sa & & & & \\
\hline
\end{tabular}

\section{Discussion}

T2DM usually becomes clinically apparent after 40 years of age [13]. T2DM seriously affects patients' quality of life and imposes a huge economic burden on national health and economy [8].

In recent years, evidence has revealed that T2DM may be due to the disorder of the natural immune system and is associated with chronic inflammation. In some studies, T2DM has been described as a disease caused by chronic inflammation, and this pathogenic role of inflammation in diabetes has been proven by many studies [14-16]. Inflammation biomarkers such as TNF-alpha, IL-6 and C-reactive protein have been reported to predict the development of $\operatorname{T2DM}[16,17]$. It has also been stated that proinflammatory cytokines can cause insulin resistance by inhibiting the transmission of insulin signal in skeletal muscle, liver and adipose tissue [18]. Another study has stated that such cytokines increase the risk of T2DM by increasing insulin resistance in fat and other tissues [19]. Three single nucleotide polymorphisms of the IL-6 promoter at positions - 174 (rs 1800795), -572 (rs 1800796) and - 597 (rs 1800797) can cause an interpersonal change in the transcription and expression of IL-6 $[13,20]$.

In this study, we found IL-6 gene rs 1800796 polymorphism to be significantly different between the control group and the T2DM patient group. The CC genotype was rare, but there was no statistically significant difference between DN + and DN- (Table 3). 
In accordance with our results, in the study conducted by Wang et al., the prevalence of IL-6 gene rs 1800796 GG genotype was $4.7 \%$ in T2DM patient group and $1.84 \%$ in the control group. There was a significant difference between the two groups; based on these data, they reported that the risk of T2DM might be high in the IL-6 gene rs 1800796 GG genotype [21]. Yin et al. showed that there is a significant relationship between the IL-6 gene rs $1800796 \mathrm{G}$ allele and the increased T2DM risk [8]. As a result of the allele model of the researchers, the risk of developing T2DM in G allele carriers has proved to be 1.29 times higher than in the $C$ allele. It has also been reported that individuals with the GG genotype have a significantly higher risk of developing T2DM compared to the GC genotype or the CC genotype. Furthermore, these researchers have suggested that SNPs at this location may be seen as candidate biomarkers for T2DM screening, diagnosis and treatment in the future [8]. Regarding rs 1800796 single nucleotide polymorphism, in a study among Caucasian Danish subjects, a significant increase in the risk of developing T2DM was shown to those carrying the $\mathrm{C}$ allele $[7,22]$.

In their study with healthy pregnant women and pregnant women with gestational diabetes in Mongolia, Zang et al. found IL-6 rs 1800796 frequencies to be CC $(21.67 \%)$, CG (37.50\%) and GG (40.83\%), allele frequencies to be $\mathrm{C}(40.42 \%)$ and $\mathrm{G}(59.58 \%)$. They found the distribution frequencies of IL-6 rs 1800796 in gestational diabetes to be CC (19.29\%), CG (54.29\%) and GG $(26.43 \%)$, allele frequencies to be C allele (46.43\%) and $\mathrm{G}$ allele (53.57\%). Based on their results, they reported that there was no significant difference between pregnancies with gestational diabetes and healthy pregnancies in terms of IL-6 rs1800796 genotypes or allele frequency [23].

Unlike our study results, in their study with the Bangladeshi participants, Pandaya et al. stated that IL-6 rs 1800796 polymorphism was not related to T2DM. Also; Pandaya et al. were reported that the circulating level of IL-6 remains elevated in people with type 2 diabetes and furthermore, this value serves as an indirect measure for the condition of insulin resistance [24].

In our study, no significant difference was found between the patients with and without DN in terms of IL6 gene rs 1800796 polymorphism genotype numbers and percentages and allele numbers and percentage values (Table 3).

There are also studies that yielded different results from ours. In their study, Chen et al. reported that IL-6 gene promoter rs 1800796 polymorphism is associated with type $2 \mathrm{DN}$, and the $\mathrm{G}$ allele may be a genetic risk factor for type $2 \mathrm{DN}$. Also, they stated that the $\mathrm{G}$ allele may increase the risk by increasing IL- 6 expression in the pathogenesis of type $2 \mathrm{DN}$ [25]. Another study conducted by Chang et al. showed that in general, rs 1800796 GG and rs 1524107 CC homozygous genotypes may pose a higher risk for the development of nephropathy in T2DM [11].

Kitamura et al. conducted a study with Japanese patients with T2DM and stated that IL-6 rs 1800796 polymorphism may be associated with and responsible for the progression of DN. They also reported that GG genotype requires confirmation of the effect of DN on the development/progression with a large-scale prospective study [9]. 
Pradhan et al. In their studies; reported that IL-6 levels in female patients with type 2 diabetes were statistically different compared to controls [15]. Unlike our results, in other studies were conducted with patients with type 2 diabetes, IL-6 levels were found to be statistically different in the control and patient groups $[12,14]$.

\section{Conclusion}

Early diagnosis of T2DM, which has a wide prevalence and economic burden throughout the world, is important for both increasing the quality of life of patients and protecting them from diabetes-related complications. Therefore, we think that it would be useful to investigate T2DM, which is known to have a genetic predisposition to early diagnosis in molecular detail and may be an auxiliary parameter for doctors. No studies have been conducted between T2DM and DN and IL-6 rs 1800796 polymorphism in Turkey. In this respect; although there are studies reporting a significant relationship between IL-6 rs1800796 polymorphism in various populations and T2DM and DN susceptibility, our findings show that IL-6 rs 1800796 polymorphism is associated with T2DM but not DN susceptibility in Turkish population. We can say that the $\mathrm{G}$ allele frequency is high in T2DM patients and can be used as a useful genetic marker.

\section{Declarations}

\section{Acknowledgements}

This study was supported by a grant of the Research Foundation of University of Artvin Coruh, Turkey (Grant No. 2018.F80.01.01). This work was supported by providing samples and diagnosing Type 2 diabetes and diabetic nephropathy patients from Dr. Sabiye ŞAHIN KESKIN. We Thank Dr. Sabiye ŞAHIN KESKIN (providing samples, diagnosing) and Mustafa Cagatay KORKMAZ (Statistical Analysis).

\section{Author's Decleration}

Nezaket Coban and Aysegul Bayramoglu participated in the study design, statistics, laboratory work method implementation, oriented the data collection and revised the manuscript critically. Zeynep Temız participated in monitoring the patients and collected blood samples. All of the authors declare that they have approved the final version.

\section{Compliance with ethical standards}

\section{Conflict of interest}

The authors declare that they have no confict of interest.

\section{Ethical approval}

The experimental procedures of the present study have been approved by the local ethics committee of Karadeniz Technical University (Protokol number: 2019/164). An informed consent was obtained from all patients prior to inclusion in this study in accordance with the Declaration of Helsinki. 


\section{Consent to participate}

All patients signed the written informed consents.

\section{References}

1. Banerjee M, Saxena M. Genetic polymorphisms of cytokine genes in type 2 diabetes Mellitus. World J Diabetes. 2014;5(4):493-504.

2. Saxena M, Srivastava N, Banerjee M. Association of IL-6, TNF-a and IL-10 gene polymorphisms with type 2 diabetes mellitus. Mol Biol Rep. 2013;40(11):6271-9.

3. Esser N, Legrand-Poels S, Piette J, Scheen AJ, Paquot N. Inflammation as a link between obesity, metabolic syndrome and type 2 diabetes. Diabetes Res Clin Pract. 2014;105(2):141-50.

4. Yalçın T, Rakıcıoğlu N. Dietary Factors. Type 2 Diabetes and Inflammation. Sakarya Med J. 2018;8(4):686-94.

5. Silva D, Pais de Lacerda A. High-sensitivity C-reactive protein as a biomarker of risk in coronary artery disease. Rev Port Cardiol (English Edition). 2012;31(11):733-45.

6. Lukic L, Lalic NM, Rajkovic N, et al. Hypertension in obese type 2 diabetes patients is associated with increases in insulin resistance and IL-6 cytokine levels: potential targets for an effi cient preventive intervention. Int J Environ Res Public Health. 2014;11(4):3586-98.

7. Zamora Ginez I, García Zapién AG, Flores Martínez SE, et al. Low prevalence of interleukin-6 haplotype sassociated with a decreased risk of type 2 diabetes in Mexican subjects with a family history of type 2 diabetes. Arch Med Res. 2013;44(7):529-34.

8. Yin YW, Sun QQ, Zhang BB, et al. Association between the interleukin- 6 gene - $572 \mathrm{C} / \mathrm{G}$ polymorphism and the risk of type 2 diabetes mellitus: a meta-analysis of 11,681 subjects. Ann Hum Genet. 2013;77(2):106-14.

9. Kitamura A, Hasegawa G, Obayashi $H$, et al. Interleukin-6 polymorphism (-634C/G) in the promoter region and the progression of diabetic nephropathy in type 2 diabetes. Diabet Med. 2002;19:1000-5.

10. Maeda S. Do inflammatory cytokine genes confer susceptibility to diabetic nephropathy? Kidney Int. 2008;74(4):413-5.

11. Chang WT, Huang MC, Chung HF, et al. Interleukin-6 gene polymorphisms correlate with the progression of nephropathy in Chinese patients with type 2 diabetes: A prospective cohort study. Diabetes Res Clin Pract. 2016;120:15-23.

12. Koh SJ, Jang Y, Hyun YJ, et al. Interleukin-6 (IL-6) 572C- promoter polymorphism is asssociated with type 2 diabetes risk in Koreans. Clin Endocrinol. 2009;70(2):238-44.

13. Xiao LM, Yan YX, Xie CJ, et al. Association among interleukin-6 gene polymorphism, diabetes and periodontitis in a Chinese population. Oral Dis. 2009;15(8):547-53.

14. Illig T, Bongardt F, Schöpfer A, et al. Significant association of the interleukin- 6 gene polymorphisms C$174 \mathrm{G}$ and A-598G with type 2 diabetes. J Clin Endocrinol Metab. 2004;89(10):5053-8. 
15. Pradhan AD, Manson JE, Rifai N, Buring JE, Ridker PM. C-reactive protein, interleukin 6, and risk of developing type 2 diabetes mellitus. JAMA. 2001;286(3):327-34.

16. Zhang X, Ma L, Peng F, et al. The endothelial dysfunction in patients with type 2 diabetes mellitus is associated with IL-6 gene promoter polymorphism in Chinese population. Endocrine. 2011;40(1):124-9.

17. Lee YH, Pratley RE. The evolving role of inflammation in obesity and the metabolic syndrome. Curr Diab Rep. 2005;5(1):70-5.

18. Kiliçlı MF, Acibucu F. Chronic Inflamation, insulin resistance and diabetes. Turkey Clinics J PharmacolSpecial Topics. 2015;3(3):30-5.

19. Badawi A, Klip A, Haddad P, et al. Type 2 diabetes mellitus and inflmmation: Prospects for biomarkers of risk and nutritional intervention. Diabetes Metab Syndr Obes. 2010; 26(3):173 - 86.

20. Terry CF, Loukaci V, Green FR. Cooperative İnfluence of Genetic Polymorphisms on İnterleukin 6 Transcriptional Regulation. J Biol Chem. 2000;275:18138-44.

21. Wang YX, Kong LF, Wang XY. The association of IL-6 gene 572C/G polymorphism and type 2 diabetes. J China Med Uni. 2010;39:1045-54.

22. Hamid YH, Rose C, Urhammer SA, et al. Variations of the interleukin-6 promoter are associated with features of the metabolic syndrome in Caucasian Danes. Diabetologia. 2005;48:251-60.

23. Zhang J, Chi H, Xiao H, Tian X, Wang Y, Yun X, Xu Y. Interleukin 6 (II-6) And Tumor Necrosis Factor A (TNF-A) Single Nucleotide Polymorphisms (Snps), Inflammation And Metabolism In Gestational Diabetes Mellitus İn Inner Mongolia. Med Sci Monit. 2017;23:4149-57.

24. Pandaya S, Saleh R, Alam A, et al. Interleukin-6 Gene Polymorphism (-572 C > G) In Type 2 Diabetes of Bangladeshi Origin. Adv Biol Res. 2016;10(3):167-74.

25. Chen J, Ning Yin Y, Sheng L, et al. The Genotype Of II-6 Gene In Patients With Type 2 Diabetic Nephropathy. Acta Med Sinia. 2009; 1-5. 